\title{
A "sabença" de Chico Buarque: um diálogo com Mário de Andrade
}

Ana Maria Clark Peres

UFMG/CNPq

\begin{abstract}
$\eta$
as diversas leituras críticas da variada produção de Chico Buarque, chama-nos a atenção o destaque de pares de oposição extraídos de sua obra, ou melhor, a tendência em se instalar o compositor-escritor num dos polos desses pares. Entre muitos levantados e tendo em vista a especificidade deste trabalho, destaco o par nacional / estrangeiro e, sobretudo, o popular / erudito.

Tanto a crítica universitária quanto a jornalística não cessam de apontar a "brasilidade" de Chico. Jogando com seu sobrenome (Buarque de Holanda), temos, por exemplo, a obra organizada por Rinaldo Fernandes, Chico Buarque do Brasil: textos sobre as canções, o teatro e a ficção de um artista brasileiro, que reúne artigos de conhecidos pesquisadores como Adélia Bezerra de Meneses, Affonso Romano de Sant'Anna, Antônio Carlos Secchin, Luiz Tatit, Regina Zilberman, entre outros. Em recente artigo, a socióloga Fabiane Batista Pinto chega a afirmar, enfaticamente, que Chico Buarque é "um embevecido por sua nação". ${ }^{1}$ Já o jornalista Fernando de Barros e Silva, na obra Chico Buarque, conclui a respeito:
\end{abstract}

Não é preciso insistir na importância de Chico Buarque para a cultura brasileira. [...] De nenhum outro compositor ou escritor contemporâneo talvez se possa dizer que a

${ }^{1}$ PINTO, 2009, p. 216. 
história do Brasil, de 1964 até hoje, passa por dentro de sua obra. $^{2}$

Curiosamente, no entanto, a formação literária desse brasileiro tão "típico" é nitidamente estrangeira:

A partir dos meus 15, 16, 17 anos [...], eu comecei a ler muito. E comecei a ler muito em francês - que ainda hoje eu escrevo melhor do que falo. Era influência da biblioteca do meu pai [o historiador Sérgio Buarque de Holanda]. O que ele mais tinha era literatura em língua francesa. E ler foi uma maneira que encontrei de me aproximar dele. [...] Ele vivia fechado na biblioteca, e eu, que tinha medo de penetrar naquele território, comecei a ler algumas coisas. Ele me indicava desde clássicos, como Flaubert, até Céline, Camus e Sartre. Li, ainda em francês, Kafka, Dostoiévski, Tolstói e uma boa dose de literatura russa. Mais prosa do que poesia. [...] Eu me lembro de, lá pelos 18 anos, ir para a Faculdade de Arquitetura com esses livros em francês, o que era uma atitude um pouquinho esnobe. Talvez para me valorizar dentro de casa ou talvez para agradar meu pai. [...] Era uma atitude um pouco exibicionista, até que um colega me deu uma debochada: "Mas você só vem com esses livros para cá, por que não lê literatura brasileira?" Eu respondi: "Você tem razão". E comecei a ler o que não havia lido até então, de Mário de Andrade, Oswald de Andrade até Guimarães Rosa, por quem me apaixonei. ${ }^{3}$

O depoimento de Chico nos leva a indagar: de que maneira interfere o estrangeiro em seu "nacional"?

Como desdobramento do nacional / estrangeiro, temos o par popular / erudito, uma vez que o nacional, na obra de Chico Buarque, é entendido muitas vezes como nacional-

2 SILVA, 2004, p. 8.

${ }^{3}$ MASSI, 1994. 
popular, como assinala Adélia Bezerra de Meneses em obra que teve sua primeira edição em 1982:

Haveria de se enfrentar ainda em Chico Buarque o problema do nacional-popular, não só por ser um assunto que aflora insistentemente em tempos de abertura, como se propõe a ser este de 1980 (quase que se torna necessário repensar o popular e o nacional como bandeira comum a todas as oposições - malgrado os riscos de deslize para... nacionalismo/populismo), mas porque, mais do que qualquer outro compositor brasileiro, Chico é estigmatizado como nacional-popular. Estigma que, por sinal, ele endossa prazerosamente $[\ldots] .^{4}$

Quanto à erudição, ela é notadamente estrangeira, como já vimos no depoimento do próprio Chico. Com um pai intelectual, altamente erudito, o jovem de 21 anos se envereda, entretanto, pela canção popular: "Meu pai [...] não me pressionou a escrever, mas apreciava quando eu escrevia. Aos 21 anos, comecei a escrever canções, e isso foi o que me seqüestrou". ${ }^{5}$ Foram necessários quase trinta anos para que o compositor popular se lançasse à escrita de romances considerados de leitura "difícil", como Estorvo, que surpreendeu a todos pela complexidade de seu enredo, fazendo com que muitos acreditassem que sua ficção estaria restrita a leitores especializados, eruditos, e não seria adequada aos ouvintes de suas canções, estas, sim, "autenticamente" populares. Mas seria possível distinguir assim tão radicalmente suas produções?

A fim de problematizar esse tipo de oposição, recorro a Mário de Andrade e ao uso que ele faz do termo "sabença", apesar da distância temporal entre ambos (Mário, nascido em

${ }^{4}$ MENESES, 2002, p. 169.

${ }^{5}$ Cf. VILLASMIL, 2005. 
1893, morre em 1945, um ano após o nascimento de Chico, em 1944). De acordo com Eneida Maria de Souza,

Poucos dentre os intelectuais do país se entregaram, de forma tão apaixonada, à questão da identidade nacional e à constituição de uma cultura voltada para todas as vertentes da sociedade. [...] $\mathrm{O}$ estreito vínculo entre a ruptura de modelos estrangeiros e a descoberta de uma tradição cultural do país foi por muito tempo esquecido, ao se privilegiar, no modernismo, a leitura pelo viés da destruição e da vanguarda, em detrimento dos valores legados pela tradição. [...] Com Mário de Andrade, percebe-se a dupla posição diante do passado: utiliza-se tanto do mecanismo de "traição da memória" como estratégia para apagar os rastros e esquecer lições herdadas da tradição, como revitaliza-se a memória dessa tradição, ao se empenhar na luta de preservação do patrimônio cultural brasileiro. [Mário] revela-se contrário à prática da memória como traço de erudição e acúmulo de saber. $\mathrm{O}$ que mais lhe importa, no ato de rememoração, é sentir-se desmemoriado, atingindo, pelo esquecimento, o salto criativo e a percepção do mundo em "perene descobrimento". A defesa do culto da sensualidade através do exercício lento e prazeroso do saber experimental - convive, de maneira contrapuntística, com a memória. ${ }^{6}$

E a ensaísta prossegue: "Mário associa o esquecimento a uma sabedoria não programada e erudita, à 'sabença' marota que desconstrói certezas e se nutre do procedimento artístico ligado à improvisação e à variação" ${ }^{7}$

É justamente na "sabença" que reside meu interesse neste trabalho. Vale lembrar que o termo não é inventado por Mário

${ }^{6}$ SOUZA, 1999, p. 179-180.

7 SOUZA, 1999, p. 180. 
de Andrade (trata-se, como se sabe, de um termo popular que exprime sabedoria, erudição), mas ele lhe atribui uma significação bem precisa, capaz justamente de anular a oposição entre o saber popular e o erudito. E é no artigo "Oswald de Andrade: Pau Brasil, Sans Pareil, 1925" que essa significação emerge. Nesse texto, ele comenta tanto o "Manifesto da Poesia PauBrasil", de 1924, quanto o livro de poemas Pau-Brasil, de 1925, ambos de Oswald de Andrade. Recortemos, pois, trechos do referido manifesto de Oswald: "A Poesia para os poetas. Alegria dos que não sabem e descobrem. [...] A língua sem arcaísmos, sem erudição. Natural e neológica. A contribuição milionária de todos os erros. Como falamos. Como somos" ${ }^{8}$

Entre outros pontos, Mário se insurge contra essas assertivas:

Osvaldo [sic] está brincando com micróbios perigosos: "contribuição milionária de todos os erros"; [...] pregando a "alegria da ignorância que descobre" e se esquecendo que tem também a alegria da sabença que descobre. E a da sabença que verifica. Duas contra uma: a da sabença é mais rica.

Ele prossegue mais adiante: "Preconceitos pró ou contra erudição não valem um derréis. O difícil é saber saber". E passa a se referir à pintora Tarsila do Amaral, que, a seu ver, personifica essa "sabença":

Afirmo que dona Tarsila do Amaral [...] está criando uma pintura esplêndida e erudita, espiritualíssima e sensorialmente dinâmica porque sabe o que é pintura como os que mais o sabem. Não repete nem imita todos os erros da pintura popular, escolhe com inteligência os fecundos, os que não são erros e se serve deles. Pintura de ateliê raciocinada no ateliê tornada erudita através dos climas palmilhados sejam

${ }^{8}$ ANDRADE, Oswald, [s.d.]. 
a tela corrediça da matriz de Tiradentes, os primitivos de Siena ou a invenção mais recente de Picasso. ${ }^{9}$

De fato, Tarsila possuía uma técnica apurada, a partir de estudos de desenho e de pintura em São Paulo e em Paris. Por exemplo, em 1923, ela estuda na capital francesa com Albert Gleizes e Fernand Léger, grandes mestres cubistas. Logo a seguir, inicia sua pintura "Pau-Brasil", em que, adotando a técnica cubista, apropria-se de cores e temas brasileiros, com forte interferência do barroco mineiro colonial, elementos esses associados aos estrangeiros, como ressaltou Mário.

Sobre essa questão, assim comenta o escritor e ensaísta Silviano Santiago no artigo "Mário, Oswald e Carlos, intérpretes do Brasil":

[...] da Europa, através da admiração que os pintores e escultores cubistas expressavam pela arte africana, vieram os óculos que nos deixaram enxergar sem preconceitos elitistas as obras-primas barrocas, aparentemente toscas, de Aleijadinho e de mestre Ataíde, até então perdidas nos escombros da Vila Rica de Ouro Preto. [...] É preciso, no entanto, insistir num detalhe. Abrasileirar-se não significa tornar-se xenófobo, ter aversão às culturas estrangeiras. ${ }^{10}$

Silviano menciona a "sabença" que Mário detectou em Tarsila, isto é, um "jogo mesclado", algo que não é "uma substância pura como o saber erudito importado da Europa" e sim um "híbrido". ${ }^{11}$ Destaca o fato de Mário sempre ter admitido que "o nosso futuro teria de passar pelo conhecimento profundo das grandes culturas estrangeiras, do passado greco-latino",, 12

\footnotetext{
9 ANDRADE, Mário de, 1972, p. 230.

${ }^{10}$ SANTIAGO, 2005, p. 9.

${ }^{11}$ SANTIAGO, 2005, p. 10.

12 SANTIAGO, 2005, p. 14.
} 
isso sem negligenciar o conhecimento dos conterrâneos e contemporâneos, "providos de falar, saber e sensualidade" ${ }^{13}$ E o ensaísta conclui seu artigo destacando o congraçamento do escritor com "a gente sofrida e alegre do povo". ${ }^{14}$

Essa última expressão de Silviano Santiago me faz retornar a Chico Buarque, mais especificamente à sua clássica canção "A Banda" (1966), cujas primeiras estrofes reproduzo:

Estava à toa na vida

O meu amor me chamou

Pra ver a banda passar

Cantando coisas de amor

A minha gente sofrida

Despediu-se da dor

Pra ver a banda passar

Cantando coisas de amor".

Provocada por Mário de Andrade, não hesito em afirmar que, vista como um todo, a obra de Chico também atesta uma "sabença". Assim como Tarsila "sabe pintura como os que mais o sabem", Chico maneja com perícia os versos de suas canções. Dono de grande erudição (como atesta o depoimento já citado), tendo acesso à biblioteca do pai, as leituras de adolescência deixam marcas em sua obra. Tal como valorizava Mário, ele não se furta ao conhecimento das culturas estrangeiras, inclusive as do passado greco-latino. Como exemplo, lembremos seu conto inaugural "Ulisses", publicado inicialmente no Suplemento Literário de $O$ Estado de São Paulo, ${ }^{15}$ e reproduzido um ano mais

\footnotetext{
13 SANTIAGO, 2005, p. 15.

14 SANTIAGO, 2005, p. 16.

${ }^{15}$ Esse conto dividiu a página 3 da edição de 30 de julho de 1966 do jornal O Estado de São Paulo com artigos de Augusto de Campos e Otto Maria Carpeaux e um soneto de Paulo Hecker Filho. Cf. WERNECK, 2006, p. 51.
} 
tarde no songbook A Banda. Nele, Ulisses é um vendedor de peças de automóveis e, para sensibilizar sua Penélope, promete-lhe não beber na rua, consertar o cano da pia, comprar uma televisão nova, entre outras trivialidades que caracterizam sua vida de homem comum. Mas é visível o diálogo que se estabelece com a obra atribuída a Homero, uma vez que trechos da Odisseia são reproduzidos no conto em questão, ainda que sob a forma de uma paródia, como o episódio em que o ciclope é embebedado com cachaça pelo Ulisses brasileiro. ${ }^{16}$ A canção "As vitrines" (de 1981), por sua vez, como bem marcou Adélia Bezerra de Meneses, "repercute ecos baudelairianos - e benjaminianos - entroncando-se na linhagem de $A$ une passante de Baudelaire" ${ }^{17}$ Sabe-se igualmente que Chico domina vários idiomas estrangeiros (francês, italiano, inglês, espanhol); por duas ocasiões morou na Itália, sendo a primeira na infância, onde estudou em escola norte-americana, e mantém já há vários anos apartamento em Paris, onde passa longas temporadas, inclusive para realizar a escrita de seus romances. ${ }^{18}$ É flagrante também seu

${ }^{16}$ BUARQUE, [s.d.].

${ }^{17}$ MENESES, 2001. Quanto a possíveis leituras de Walter Benjamin por parte de Chico, um detalhe me chamou a atenção no recente documentário Palavra (en)encantada, de Helena Solberg (2009). O compositor-escritor se deixa entrevistar junto a um piano e podemos ver, sobre este, Passagens, obra de Benjamin publicada no Brasil pela Editora UFMG, em 2006. Quanto ao diálogo com Baudelaire, também a canção "Ode aos ratos" (2001) o explicita, trazendo versos ("Ó meu semelhante / Filho de Deus, meu irmão") que ecoam os de "Au lecteur", do poeta francês: "Hypocrite lecteur, - mon semblable, - mon frère!".

${ }^{18}$ Sobre as interferências da cultura francesa na vida e obra de Chico Buarque, remeto o leitor para meu artigo "A França de Chico Buarque", publicado no v. 18, n. 1, de O Eixo e a Roda. 
cuidado com a língua portuguesa, atestado em vários depoimentos e relatos biográficos, que falam de seus manuais de gramáticas e diversos dicionários, muitos deles herdados do pai. No entanto, ele foi "sequestrado" pelo popular, como já citado, e soube realizar a mescla, o híbrido, que constitui a "sabença": memória da erudição, resgate da memória popular, mas ao mesmo tempo "traição da memória", "esquecimento" que propicia a invenção. Musicalmente, Chico "reatou com Noel Rosa, com o samba; também com a marcha-rancho, a modinha, a valsa brasileira; com o Brasil, enfim, no que tem ou no que tinha de mais delicado, de mais simples, de mais digno", no dizer do jornalista Marcelo Coelho. ${ }^{19}$

Para tornar mais clara sua "sabença", bem como os deslocamentos que esta sofre, creio ser importante me deter passo a passo em sua obra, ainda que por meio de um breve recorte.

Na década de 60, é flagrante sua opção pelo brasileiro comum e pela sabedoria popular e proverbial. Ele busca retratar (as expressões que se seguem são extraídas de letras de suas canções): toda a gente, todo mundo, a gente sofrida, a cidade, a criança, a meninada, a mulher, a morena, a mulata, a moça feia, a moça triste, a namorada, o homem que trabalha, o pedreiro, o funcionário, mas também aquele que é sem compromisso, sem relógio e sem patrão, o homem sério que conta dinheiro, o faroleiro, o velho fraco, o homem que chora, o folião que se veste de rei no carnaval, o sambista que mora em barraco, que foi criança comum (brincou de bola, soltou balão) e que fugiu da escola. Emblematicamente, em "Tamandaré" (1965), fala de um "Zé qualquer".

Na recuperação da memória da tradição popular, as letras de suas composições trazem ditados e expressões que

${ }^{19}$ COELHO, 1991. 
estão na boca do povo, às vezes com pequenas alterações: "A maré não tá boa", "Não vou dar braço pra ninguém torcer", "Meu santo é forte", "Madalena foi pro mar e eu fiquei a ver navios", "Seja o que Deus quiser", "Me despacha pro batente", "Tirar leite das pedras" etc. Um exemplo paradigmático desse resgate é "A Banda" (1966), que assim foi saudada pelo poeta Carlos Drummond de Andrade:

O jeito, no momento, é ver a banda passar, cantando coisas de amor. Pois de amor andamos todos precisados, em dose tal que nos alegre, nos reumanize, nos corrija, nos dê paciência e esperança, força, capacidade de entender, perdoar, ir para a frente. Amor que seja navio, casa, coisa cintilante, que nos vacine contra o feio, o errado, o triste, o mau, o absurdo e o mais que estamos vivendo e presenciando. [...] A felicidade geral com que foi recebida essa banda tão simples, tão brasileira e tão antiga na sua tradição lírica, que um rapaz de pouco mais de vinte anos botou na rua, alvoroçando novos e velhos, dá bem a idéia de como andávamos precisando de amor. [...] E se o que era doce acabou, depois que a banda passou, que venha outra banda, Chico, e que nunca uma banda feito essa deixe de musicalizar a alma da gente. ${ }^{20}$

Como afirma Caetano Veloso, em entrevista concedida à revista Código, de agosto de 1980, Chico, sobretudo no período em questão, "anda pra frente arrastando a tradição". ${ }^{21}$

Nesses anos 60 percebemos a desenvoltura do letrista em adotar, por exemplo, uma métrica tradicional, como a redondilha menor (lembremos de "Meu Refrão"), e de incorporar com esmero o sambista popular, mas é na década de 70 que sua técnica fica mais apurada e visível. Já em “Construção" (1971),

${ }^{20}$ ANDRADE, Carlos Drummond de, 1996. Grifo meu.

${ }^{21}$ Cf. MENESES, 2002, p. 28. 
poema de versos dodecassílabos, que "obedece a um rígido esquema estrutural", apresenta-se, no dizer de Adélia Bezerra de Meneses, "sua poderosa força artesanal".22 O compositor também não recua diante de poemas de forma fixa, como é o caso de "Soneto" (1972), mas curiosamente um ponto se destaca, qual seja: a tradição popular é subvertida, por meio de recursos variados.

Em “Bom Conselho" (1972), por exemplo, ele brinca com provérbios: "Ouça um bom conselho / Que eu lhe dou de graça",23 "Inútil dormir que a dor não passa";24 "Espere sentado / Ou você se cansa"; 25 "Está provado, quem espera nunca alcança", 26 "Brinque com meu fogo / Venha se queimar",;7 "Faça como eu digo / Faça como eu faço"; 28 "Aja duas vezes antes de pensar"; 29 "Corro atrás do tempo"; 30 "Devagar é que não se vai longe"; 31 "Eu semeio vento na minha cidade / Vou pra rua e bebo a tempestade". ${ }^{32}$ Note-se que essa inversão proverbial, que visa problematizar, sacudir o conformismo e a acomodação inconcebíveis em tempos de uma ditadura que tortura e mata,

${ }^{22}$ MENESES, 2002, p. 147-148.

${ }^{23}$ Vejamos o provérbio correspondente: "Conselho, se fosse bom, ninguém dava, vendia".

24 "Dorme, que a dor passa".

25 "Pode esperar sentado".

26 "Quem espera sempre alcança".

27 "Quem brinca com fogo acaba se queimando"

28 "Faça o que eu digo, não faça o que eu faço".

29 "Pense duas vezes antes de agir".

30 "Não corra atrás do tempo".

31 "Devagar se vai longe"

32 "Quem semeia vento, colhe tempestade"; "Não faça tempestade em um copo d'água". 
é feita pelo compositor por meio de uma técnica cuidadosa, "num esquema de recorrências fônicas, em que a sonoridade cria relações de tensão entre as palavras". ${ }^{33}$

É na mesma década de 70 que a cultura estrangeira interfere explicitamente em suas canções. Em "Joana francesa" (1973), composta para o filme homônimo de Cacá Diegues, para ser tema da personagem (uma dona de bordel) interpretada pela atriz francesa Jeanne Moreau, a erudição do compositor, isto é, o domínio do idioma francês, mescla-se à sensualidade nativa e a elementos bem brasileiros. Eis as duas últimas estrofes da letra:

Vem molhar meu colo

Vou te consolar

Vem, mulato mole

Dançar dans mes bras

Vem, moleque me dizer

Onde é que está

Ton soleil, ta braise

Quem me enfeitiçou

O mar, marée, bateau

Tu as le parfum

De la cachaça e de suor

Geme de preguiça e de calor

Já é madrugada

Acorda, acorda, acorda, acorda, acorda" ${ }^{34}$

Em 1974, é a vez de o compositor investir novamente na ficção, com a publicação da "novela pecuária" Fazenda modelo,

\footnotetext{
33 MENESES. 2002, p. 187.

${ }^{34}$ Curiosamente, no verso "O mar, marée, bateau", podemos ler tanto palavras soltas ligadas ao contexto marítimo (mar, maré, barco), quanto escutar uma frase em português relacionada a esse contexto: "O mar m'arrebatou". A repetição de "acorda, acorda, acorda", por sua vez, soa como d'acord, d'acord.
} 
uma alegoria do Brasil da ditadura, e que foi imediatamente associada à obra de George Orwell, A revolução dos bichos. Na novela buarquiana, de acordo com Regina Zilberman, estabelece-se

um paralelo entre o espaço escolhido para a representação fictícia e a nação brasileira. Nada melhor do que o recurso aos chavões com que o país vem sendo traduzido desde o século XIX, explorado exaustivamente pela literatura no Romantismo e pela cultura popular no Modernismo. É esse o papel desempenhado pelo parágrafo inicial do primeiro capítulo: "Era assim: o que quiser que tenha, tinha. Tinha arrebol? Tinha. Rouxinol? Tinha. Luar do sertão, palmeira imperial, girassol, tinha". À manifestação ufanista seguese, contudo, a revelação das mazelas, neutralizando a perspectiva eufórica a que a abertura podia conduzir: "Também tinha temporal, barranco, às vezes lamaçal, o diabo" ${ }^{35}$

Assim como em "Bom conselho", aqui Chico se apropria da tradição para subvertê-la.

Em "Teresinha" (1978), composta para a peça Ópera do malandro, o compositor incorpora o folclore, mais exatamente a cantiga de roda "Terezinha de Jesus" (aquela que "de uma queda foi ao chão", sendo acudida por três cavalheiros, "todos três chapéu na mão"), misturando-a com uma canção de Brecht, "Barbara's Lied", da Ópera dos Três vinténs, isso tudo em meio a uma cuidadosa elaboração formal, em jogos de sons e sentidos. ${ }^{36}$

35 ZILBERMAN, 2004, p. 365.

${ }^{36}$ A esse respeito, remeto o leitor para o estudo da canção feito por Adélia Bezerra de Meneses. MENESES, 2001, p. 107-118. Vejamos na íntegra a letra de "Teresinha", de Chico: "O primeiro me chegou / Como quem vem do florista / Trouxe um bicho de pelúcia / Trouxe um broche de ametista / Me contou suas viagens / E as vantagens que ele tinha / Me mostrou o seu relógio / Me chamava 
Mas é em "Canção de Pedroca" (1979), composta em parceria com Francis Hime para o musical O Rei de Ramos, de Dias Gomes, cuja ação se passa no mundo do jogo do bicho, que a mistura entre a cultura francesa e a brasileira se apresenta mais nitidamente, sendo capaz de evocar, inclusive, uma conhecida pintura de Tarsila do Amaral, "Carnaval em Madureira", de 1924, que instala a Torre Eiffel no subúrbio carioca de Madureira:

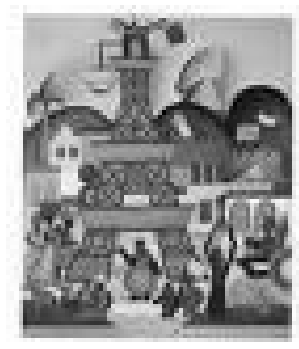

Vale a pena citar na íntegra a letra da canção:

Quando nos apaixonamos

Poça d'água é chafariz

Ao olhar o céu de Ramos

Vê-se as luzes de Paris

de rainha / Me encontrou tão desarmada / Que tocou meu coração/ Mas não me negava nada / E, assustada, eu disse não / O segundo me chegou / Como quem chega do bar / Trouxe um litro de aguardente / Tão amarga de tragar / Indagou o meu passado / E cheirou minha comida / Vasculhou minha gaveta / Me chamava de perdida / Me encontrou tão desarmada / Que arranhou meu coração / Mas não me entregava nada / E, assustada, eu disse não / O terceiro me chegou / Como quem chega do nada / Ele não me trouxe nada / Também nada perguntou / Mal sei como ele se chama / Mas entendo o que ele quer / Se deitou na minha cama/E me chama de mulher / Foi chegando sorrateiro / E antes que eu dissesse não / Se instalou feito um posseiro / Dentro do meu coração". 
No verão é uma delícia

A brisa fresca de Bangu

Mesmo um cabo de polícia

Só nos diz merci beaucoup

Eu ouço um samba de breque

Com Maurice Chevalier

Bebo com Toulouse-Lautrec

No bar do Caxinguelê

Daí ninguém mais estranha

O Louvre na Praça Mauá

E o borbulhar de champanha

Num gole de guaraná

Cascadura é Rive Gauche

O Mangue é Champs Elysées

Até mesmo um bate-coxa

Faz lembrar um pas-de-deux

Purê de batata roxa

Parece marron glacê.

Nessa letra, o compositor aproveita elementos significativos de ambas as culturas, mesclando-os com perícia: o chansonier francês Maurice Chevalier canta um samba de breque brasileiro; o pintor Toulouse-Lautrec, que tanto se ocupou da vida boêmia parisiense, agora se instala no coração da boemia da zona norte do Rio de Janeiro; o Louvre, emblema da civilização ocidental, idem; a sofisticação do champagne francês se mistura ao nosso guaraná; o pas-de-deux do balé clássico se funde ao popular "bate-coxa"; o marron glacé, ao brasileiríssimo purê de batata doce.

Na década de 80, a "sabença" de Chico ganha outros contornos. Em tempos de globalização, ele usa sua técnica para misturar o nacional e o norte-americano, como em "Hollywood" (1981), do filme Saltimbancos Trapalhões: "Ói nós aqui / Ói nós aqui / Hollywood fica / Ali bem perto / Só não vê quem / 
Tem um olho aberto [...] / Ói nós aqui / Ói nós aqui / How do you do / Caruaru" ${ }^{37}$ Em "Rebichada" (1981), do mesmo filme, ao reinventar a história dos músicos de Bremen, dos irmãos Grimm, também é enfatizada a mistura do estrangeiro e do nacional, além da persistência da tradição. Vejamos um trecho da letra:

Essa fábula vem de outro século

Pelo fascículo de um alemão

O irmão do alemão deu prum nego

Que vendeu prum grego

Por meio milhão

Esse grego morreu de embolia

E deixou para a tia

O que tinha na mão

Essa tia casou com um pirata

E afundou com a fragata

Lá no Maranhão

Essa lenda rolou na fazenda

Moeu na moenda

E espalhou no sertão

E eu não nego que roubei dum cego

E inda ponho no prego

Pra comprar meu pão

Não sou eu quem repete essa história

É a história que adora

Uma repetição

Uma repetição.

Em “Las muchachas de Copacabana" (1985), confrontamosnos com uma mistura latino-americana: "Se o cliente quer

${ }^{37}$ Ressalte-se que a feira de Caruaru, em Pernambuco, foi considerada pelo Instituto do Patrimônio Histórico e Artístico Nacional (IPHAN) como patrimônio imaterial do Brasil. 
rumbeira, tem / Com tempero da baiana / Somos las muchachas de Copacabana / Cubanita brasileira, tem / Com sombreiro à mexicana / Somos las muchachas de Copacabana".

Em "Imagina" (1983), Chico se apropria de uma mescla entre o saber erudito e o popular, para produzir uma letra requintada, à altura da melodia de Tom Jobim. Seu tema é a "lua cris", expressão arcaica para designar o eclipse da lua. De acordo com o Dicionário do folclore brasileiro, de Câmara Cascudo, ${ }^{38}$ alia-se, aqui, a superstições arcaicas, o conhecimento científico quanto ao influir cósmico, fazendo com que se acredite que a "lua cris" (o eclipse lunar) provoca sofrimentos, infortúnios, desgraças e doenças. Por meio de belas imagens, o compositor se refere a esse eclipse:

Imagina

Hoje à noite

A lua se apagar

Quem já viu a lua Cris?

Quando a lua começa a murchar

Lua cris

É preciso gritar e correr

Socorrer o luar

Meu amor

Abre a porta para a noite passar".

E Chico acrescenta à letra de sua canção uma velha crença popular: "Sabe que o menino que passar debaixo do arco-íris vira moça, vira / A menina que cruzar de volta o arco-íris rapidinho volta a ser rapaz". ${ }^{39}$

${ }^{38}$ CASCUDO, [s.d.].

${ }^{39}$ De acordo com Tom Jobim, seria quase impossível pôr letra em sua melodia, composta como instrumental, mas Chico conseguiu fazê-lo, agradando bastante o maestro. 
Em "Baticum" (1989), composta em parceria com Gilberto Gil, deparamos com uma mistura entre a tradição popular, o "baticum" (ruído de sapateado e palmas, como no batuque), e a globalização. Todos são convidados para um "baticum":

Veio Mané da Consolação

Veio o Barão de lá do Ceará

Um professor falando alemão

Um avião veio do Canadá

Monsieur Dupont trouxe o dossier

E a Benetton topou patrocinar

A Sanyo garantiu o som

Do baticum lá na beira do mar

[...]

A Warner gravou

E a Globo vai passar.

[...]

Zeca pensou: antes que era bom

Mano cortou: brother, o que é que há

Foi a G.E. quem iluminou

E a Macintosh entrou com o vatapá

O JB fez a crítica

E o cardeal deu ordem pra fechar

O Carrefour, digo, o baticum

Da Benetton, não, da beira do mar".

Ainda na década de 80, vale destacar "O futebol" (1989), canção em que um dos traços da singularidade do futebol brasileiro (tão popular no Brasil), o chamado "corta-luz", ${ }^{40}$

40 "[...] a bola, conduzida por um jogador numa seqüência supostamente linear, está subitamente nos pés de um outro do mesmo time que se interpõe cruzando a sua trajetória. Ou então: a bola vem na direção de um jogador que cruza a sua trajetória sem pegá-la, deixando-a de surpresa para outro [...]". WISNIK, 2008, p. 310. 
comparável à elipse, é reproduzido justamente pelo uso da figura de linguagem. Nessa canção, utilizando-se de uma técnica apurada, Chico compara o trabalho do artista, em geral, ao do craque de futebol, além de procurar resgatar a memória dos momentos brilhantes de jogadores brasileiros do passado, já que a composição tem uma dedicatória que reproduz, aliás, vários dribles: "Para Mané [Garrincha] para Didi para Mané para Didi para Mané para Didi para Pagão para Pelé para Pelé e Canhoteiro".

Nessa década de 80, o compositor continua a se apropriar de expressões populares: "Jogar confete", "Cê tá de lascar / Cê tá de doer", "Quem tapava esse sol com a peneira", "Comer e cuspir no prato", "Ir para uma melhor". Ressaltem-se, em especial, duas canções: "Tororó" (1987), em parceria com Edu Lobo, cuja primeira estrofe reproduz uma conhecida cantiga de roda ("Fui à fonte do Tororó beber água não achei"), e "A permuta dos santos" (1988), em que se apresenta um recurso da cultura popular, isto é, o de "contrariar" os santos: "levavase para ali o S. Sebastião da igreja local, trazendo-se, em troca, [...] a imagem do Senhor do Bonfim, tudo processionalmente, com rezas e cânticos. Enquanto não chovia os santos não voltavam para seus lugares" ${ }^{41}$

Na década de 90, ao lado da publicação de romances de leitura "difícil" (Estorvo e Benjamim), Chico insiste em compor canções de forte apelo popular, como "Biscate" (1993), "De volta ao samba" (1993), "Nego maluco" (1993), "Piano na Mangueira" (1993), "Chão de Esmeraldas" (1997), além da emblemática "Paratodos" (1993). Em duas canções, "Assentamento" (1997) e "Levantados do chão" (1997), ambas feitas para o livro Terra, do fotógrafo Sebastião Salgado, sobre o Movimento dos Sem-Terra, o diálogo é com Guimarães Rosa (a primeira) e com

${ }^{41}$ CASCUDO, [s.d.]. 
José Saramago (a segunda). Em "Carioca" (1998), o popular urbano do Rio de Janeiro, muito comum na obra do compositor, apresenta-se como uma mistura: ao lado do sambista, dos voadores de asa-delta, do vendedor de pamonhas e das prostitutas de Copacabana, temos os religiosos que pregam em praça pública.

Neste início do século XXI, assistimos ainda ao compositor se voltando para o saber popular ebuscando, quem sabe, manter a "pureza" e a integridade desse saber:

Forrobodó é folguedo

De reis

Forrobodó de preto forro

Tem o forrobodó na praia, iaiá

Tem o forrobodó no Morro

[...]

Forrobodó para o inglês

Pode ser for everybody, e não falseia

Quem saboreia se enamora

Mas não leva embora meu forrobodó.

É em Leite derramado, contudo, seu último romance, publicado em março de 2009, que a questão da memória (também) do saber popular se apresenta de forma mais instigante. Nele, escancara-se a fala desconectada do centenário narradorpersonagem Eulálio d'Assumpção, que, num leito de hospital, relembra sua história, constituindo-se, no dizer de Leyla Perrone-Moisés, "uma saga familiar caracterizada pela decadência social e econômica, tendo como pano de fundo a história do Brasil dos últimos dois séculos" ${ }^{42} \mathrm{O}$ título já nos remete a um velho ditado: "Não chores pelo leite derramado". Em outros termos: há algo que se perdeu e em torno desse objeto perdido se constrói a narrativa. É importante ressaltar igualmente que

42 PERRONE-MOISÉS, 2009. 
esse título evoca uma fábula de La Fontaine, La Laitière et le pot au lait, publicada em Fables (1678), história da menina Perrette, que carrega uma bilha de leite ao mesmo tempo em que devaneia fortunas a partir de sua venda. Esses devaneios são interrompidos, entretanto, pela queda da bilha e pela visão do leite derramado. Câmara Cascudo, em estudo sobre essa história, remonta a trecho do "Auto da Mofina Mendes", de Gil Vicente (1534), que trata de um pote de azeite que também se derrama. Ele faz referência igualmente a diversas outras versões semelhantes, de diferentes épocas, inclusive uma indiana, o que indica se tratar de um motivo enraizado na tradição popular de vários países. ${ }^{43}$ Note-se que a tradição se apresenta, de fato, como a porta de entrada do romance de Chico Buarque, cujo enredo também se inicia com o resgate de um valor enraizado: "Quando eu sair daqui, vamos nos casar na fazenda da minha feliz infância, lá na raiz da serra" ${ }^{44}$ fazenda essa que é lembrada em vários momentos da narrativa e traz em sua esteira brincadeiras antigas (soltar pipa, fazer arapuca de caçar passarinho, realizar malabarismos com uma laranja nos pés), todas aprendidas com um escravo. A linguagem popular tem seu espaço no enredo: "Preço de banana", "Bom dia, flor do dia", "Cantiga do boitatá-pega-neném" etc.

Em entrevista concedida à jornalista portuguesa Isabel Coutinho, em 17/07/09, Chico assim se refere à questão da linguagem do livro, quando indagado a respeito de uma expressão utilizada ("Em mil seiscentos e lá vai fumaça"):

Engraçado que eu quase usei uma expressão portuguesa, "mil novecentos e carqueja". Li não sei onde, mas não está nos meus dicionários e acabei por deixar de lado. Aqui

${ }^{43}$ CASCUDO, [s.d.].

${ }^{44}$ BUARQUE, 2009, p. 5. 
ninguém ia perceber. "E lá vai fumaça" era o mais usado no Brasil, mas também fora de moda. ${ }^{45}$

Observe-se que, no romance, o saber popular se apresenta mesclado ao erudito, como já vinha acontecendo em canções do compositor desde a década de 80. Matilde, uma mestiça, a mulher amada pelo narrador, realiza essa mescla:

Ainda éramos namorados no dia em que ela sentou ao Pleyel de minha mãe, e me preparei para escutar alguma peça de Mozart, compositor que ela cantara, ou fingira cantar, na missa de sétimo dia do meu pai. Mas com a mão pesada, ela tocou um batuque chamado Macumba Gegê, vá saber onde aprendeu aquilo. E mamãe se despencou pela escada, para ver que diabo se passava. ${ }^{46}$

Ressalte-se igualmente que Chico apresenta a tradição popular com técnica e erudição, reafirmando sua "sabença" também na ficção. Como conclui Leyla Perrone-Moisés, "o texto é construído de forma primorosa, no plano narrativo como no plano do estilo. [...] Tudo, neste texto, é conciso e preciso. [...] Leite derramado é obra de um escritor em plena posse de seu talento e de sua linguagem". ${ }^{47}$ Muitos comentadores da obra já encontraram nela, inclusive, ecos de Dom Casmurro, de Machado de Assis, não apenas na figura de Matilde (reedição renovada de Capitu?), como no comportamento do velho Eulálio, que, com a partida da mulher, torna-se um ermitão.

Antes de finalizar, retornemos brevemente a outros pontos do enredo de Leite derramado e à questão da memória da tradição popular. Hoje, a fazenda antiga da infância é um sonho, no qual o centenário narrador encontra seu avô de barba

\footnotetext{
${ }^{45}$ COUTINHO, 2009.

${ }^{46}$ BUARQUE, 2009, p. 45.

${ }^{47}$ PERRONE-MOISÉS, 2009.
} 
e suíças brancas, que "está enterrado no cemitério familiar da fazenda na raiz da serra, com capela abençoada pelo cardeal arcebispo do Rio de Janeiro", ${ }^{48}$ mas um sonho em ruínas: "Confesso que, para mim, era um pouco melancólico [mesmo em tempos idos] ver as ruínas da sede colonial, a capela em esqueleto, o estábulo carbonizado, a relva seca e a terra estéril da fazenda da minha infância". ${ }^{49}$ Se essa fazenda nos traz ecos de um saber popular, poderíamos afirmar que há aqui uma certa tradição em ruínas? Ora, em outro trecho, o narrador assinala que, nos escombros da capela "que o cardeal arcebispo do Rio de Janeiro abençoou em mil oitocentos e lá vai fumaça", vê-se o letreiro "Igreja do Terceiro Templo". ${ }^{50}$ Conclui-se, assim, que um passado e uma tradição se perderam, como o leite do pote da menina Perrette; cabe ao narrador tão somente tentar resgatá-los pela memória. Mas sabemos que essa memória não volta inteira (ainda de acordo com Leyla Perrone-Moisés, é "uma memória desfalecente, repetitiva, mas contraditória, obsessiva, mas esburacada" ${ }^{11}$ ): o que sobra são cacos ou ecos dela. Restos que doem ("A memória é uma vasta ferida", afirma o narrador ${ }^{52}$ ) e que, em última instância, causam a ficção de Chico Buarque. Aliás, o próprio autor declara ser o relato de seu último romance um apanhado de restos da voz do pai. $\mathrm{Na}$ entrevista já citada, ele afirma:

Conscientemente não há influência dos livros de meu pai. Há a presença do meu pai porque ele é um historiador e os estudos e o trabalho dele normalmente vazavam para a

\footnotetext{
${ }^{48}$ BUARQUE, 2009, p. 15-16.

${ }^{49}$ BUARQUE, 2009, p. 79.

${ }^{50}$ BUARQUE, 2009, p. 178.

51 PERRONE-MOISÉS, 2009.

${ }^{52}$ BUARQUE, 2009, p. 10.
} 
conversa do dia-a-dia. Não que se fosse conversar sobre a história do Brasil o tempo todo. Inclusive eu citei lá coisas anedóticas que ele gostava muito. O que ele não podia usar, porque não cabia no tom dos livros dele, os restos dessas histórias, a pequena história, eram assuntos lá em casa. Pequenas coisas sem importância que nas pesquisas ele descobria, que eram engraçadas, mas não faziam parte do repertório dele oficial, do que era escrito. Mas que ele comentava. ${ }^{53}$

Concluindo, percebemos que é variadíssimo o saber popular que Chico Buarque resgata em sua obra, bem como as formas (sofisticadas) de tratá-lo. Não se acomodando em um pensamento binário, podemos afirmar, pois, que nessa obra o autor nos transmite um tipo específico de sabedoria: nãoíntegra, feita de furos em saberes constituídos, sejam eles populares ou eruditos. Em outros termos, uma "sabença" que soube se renovar para além das proposições de Mário de Andrade-e, sempre, com o máximo de sabor possível.

\section{Referências}

ANDRADE, Carlos Drummond de. Notas sobre A Banda. Disponível em: <http://www.chicobuarque.com.br/construcao/mestre.asp? pg=notas $/$ n_abanda.htm >. Acesso em: 4 fev. 2008.

ANDRADE, Mário de. Oswald de Andrade: Pau Brasil, sans pareil, 1925. In: BATISTA, M. R.; LOPEZ, T. P.; LIMA, Y. S. Brasil:1 tempo modernista - 1927/29; documentação. São Paulo: IEB, 1972. p. 225-232.

ANDRADE, Oswald. Manifesto antropofágico. Disponível em: $<$ http:/ / antropofagia. uol.com.br/manifestos/antropofagico $>$. Acesso em: 15 set. 2010.

${ }^{53}$ Cf. COUTINHO, 2009. Grifos meus. 
BENJAMIN, Walter. Passagens. Belo Horizonte: Editora UFMG, 2006. BUARQUE, Chico. Leite derramado. São Paulo: Companhia das Letras, 2009.

BUARQUE, Chico. Ulisses. Disponível em: <http://www.chico buarque.com.br/livros/ mestre.asp? pg=conto_ulisses. htm >. Acesso em 03 jun. 2009

CASCUDO, Luís da Câmara. Dicionário do folclore brasileiro. Disponível em: <http:/ / www.chicobuarque.com.br/construcao/ mestre.asp?pg=imagina_83.htm>. Acesso em 20 out. 2009.

CASCUDO, Luís da Câmara. Dicionário do folclore brasileiro. Disponível em: <http:/ / www.chicobuarque.com.br/construcao/ mestre.asp?pg=apermuta_87.htm>. Acesso em: 15 out. 2009.

CASCUDO, Luís da Câmara. O poldrinho sertanejo e os filhos do vizir do Egito. Disponível em: <http:/ / www.mcc.ufrn.br/portalda memoria/wordpress/wp-content/uploads/2009/07/ PoldrinhoBANDO.pdf>. Acesso em: 1 out. 2010.

COELHO, Marcelo. Folha de S. Paulo, 03/08/91. Disponível em: <http://www.chicobuarque. com.br/critica/mestre.asp?pg= estorvo_critica.htm>. Acesso em: 18 set. 2010.

COUTINHO, Isabel. O que é que Chico tem. Ípsilon, 17/07/09. Disponível em: <http://www.chicobuarque.com.br/critica / mestre.asp?pg=leite_critica.htm>. Acesso em: 5 ag. 2009

FERNANDES, Rinaldo de (Org.). Chico Buarque do Brasil: textos sobre as canções, o teatro e a ficção de um artista brasileiro. Rio de Janeiro: Garamond, 2004.

MASSI, Augusto. Chico Buarque volta ao samba e rememora 30 anos de carreira. Disponível em: <http:/ / www.chicobuarque. com.br/ texto/mestre.asp?pg=entrevistas/entre_09_01_94.htm>. Acesso em: 05 jan. 2009.

MENESES, Adélia Bezerra de. Desenho mágico: poesia e política em Chico Buarque. 3. ed. São Paulo: Ateliê Editorial, 2002. 
MENESES, Adélia Bezerra de. Figuras do feminino na canção de Chico Buarque. 2. ed. São Paulo: Ateliê Editorial, 2001.

PALAVRA (en)cantada. Direção: Helena Solberg, 2009.

PERES, Ana Maria Clark. A França de Chico Buarque. O Eixo e a Roda: Revista de Literatura Brasileira, Pós-Lit/UFMG, Belo Horizonte, v. 18, n. 1, p.15-36, jan./jun.2009.

PERRONE-MOISÉS, Leyla. [Orelha do livro]. BUARQUE, Chico. Leite derramado. São Paulo: Companhia das Letras, 2009.

PINTO, Fabiane Batista. Os brasileiros de Chico Buarque. In: SOUZA, Marly G. C. (Org.). Diálogo entre literatura e outras artes. João Pessoa: Editora da UFPB, 2009.

SANTIAGO, Silviano. Mário, Oswald e Carlos, intérpretes do Brasil. Alceu: Revista de Comunicação, Cultura e Política, Departamento de Comunicação Social da PUC-Rio, Rio de Janeiro, v.5, n.10, p. 5-17, jan./jun. 2005.

SILVA, Fernando Barros e. Chico Buarque. São Paulo: Publifolha, 2004. (Coleção Folha Explica).

SOUZA, Eneida Maria de. A pedra mágica do discurso. 2. ed. ver. e aum. Belo Horizonte: Editora UFMG, 1999.

VILLASMIL, Alejandra. Diálogo entre Chico Buarque e Paul Aster abre festival literário em NY. UOL, 18/04/2005. Disponível em: <http://www.chicobuarque.com.br/texto/ mestre.asp?pg= entrevistas/entre_uol_180405.htm>. Acesso em: 11 nov. 2008.

WERNECK, Humberto. Na vertigem da roda-viva. In: BUARQUE, Chico. Tantas palavras. São Paulo: Companhia das Letras, 2006. p. 41-64.

WISNIK, José Miguel. Veneno remédio: o futebol e o Brasil. São Paulo: Companhia das Letras, 2008.

ZILBERMAN, Regina. Não é conversa mole pra boi dormir. In: FERNANDES, Rinaldo de. (Org.). Chico Buarque do Brasil: textos sobre as canções, o teatro e a ficção de um artista brasileiro. Rio de Janeiro: Garamond, 2004. p. 363-370. 


\section{Resumo:}

Este trabalho pretende abordar as imbricações do nacional e do estrangeiro, e, sobretudo, do popular e do erudito na obra de Chico Buarque, à luz da noção de "sabença", ressignificada por Mário de Andrade.

\section{Résumé:}

Ce travail prétend aborder les imbrications du national et de l'étranger, et, surtout, du populaire et de l'érudit dans l'œuvre de Chico Buarque, à la lumière de la notion de "sabença", re-signifiée par Mário de Andrade. 